\section{British Iron and Steel Research Association: Appointments}

THE following announcements have recently been made by the British Iron and Steel Research Associztion :

MT. M. W. Thring has been appointed head of the Physies Department. Mr. Thring has been with the British Coal Utilisation Research Association for many years, and recently has been in charge of the Furnace Research Section and Combustion Research Laboratories. For the past eighteen months he and a large part of his team have been engaged on a cooperative research with Dr. J. H. Chesters and the United Steel Companies, Ltd., into the study of flames in furnaces; the 'down jet' method of combustion and the use of radon for studying gas flow in furnaces were originated by this team. Mr. Thring has also written papers on the laws governing energy flow in heating appliances, starting to form a link between Gibbsian thermostatics and industrial thermodynamics.

Dr. W. C. Newell, until recently on the staff of the Brown-Firth Research Laboratories, Sheffield, has been appointed head of the.Steel Castings Division. Dr. Newell received his training and research experience at the Royal College of Science.

Mr. E. L. Diamond has been appointed mechanical engineer to the Plant Engineering Division. $\mathrm{Mr}$. Diamond graduated in engineering with honours at King's College, London, in 1922, and then became a pupil of the late Sir Henry Fowler at the Derby locomotive works of the Midland Railway, later assisting in experimental work. Since 1926 he has been on the technical staff of the Institution of Mechanical Engineers, except during the war years. He has published a number of papers on technical locomotive problems.

\section{Beit Memorial Fellowships for Medical Research}

Aт a recent meeting of the trustees of the Beit Memorial fiellowships, it was announced that Sir John Apterson and Sir Henry Dale had been elected trusteos; Lord Rayleigh and Lord Macmillan have resjoned from the board. The Trustees noted with pleasure that Dr. E. B. Verney (fellow 1922-26) had been elected professor of pharmacology, Cambridge; Dr. Janet Vaughan (1931-34), principal of Somerville College, Oxford; Dr. B. G. Maegraith (1933-34), professor of tropical medicine, Liverpool ; Dr. J. S. Mitchell (1934-37), professor of radiotherapeutics, University of Cambridge; Dr. R. J. Kellar (1935-37), professor of midwifery, University of Edinburgh ; and that Dr. R. J. Hill (1929-31) and Dr. G. R. Cameron (1930-33) had been elected to the fellowship of the Royal Society.

The following elections were made: Fourth Year Fellowships. Dr. G. J. Popjak, to study the behaviour of plasma lipids under different experimental conditions and the problem of fœetal fat metabolism (at the Department of Pathology, St. Thomas's Hospital, London) ; Dr. Ethel G. Teece, to study the chemistry of bacterial polysaccharides and nucleoproteins with special reference to the Gram complex and to the factors responsible for cell division (at the Department of Chemistry, University of Birmingham). Junior Fellowships. Dr. S. E. Dicker, to study the extrarenal water metabolism and renal function in rats (at the Department of Pharmacology, University of Bristol) ; P. M. Tow, to study prefrontal leucotomy and the function of the frontal area (at the Research Department, Runwell Hospital for Nervous and Mental Diseases).

\section{University of London}

THE following appointments have been announced:

Dr. Jareslav Cerny, to the University chair of Egyptology tenable at University College as from October 1. During 1927-33 he worked in the Department of Antiquities, Egyptian Government; he accompanied the Harvard University Expedition to Sinai in 1935 and during 1942-45 he was in the Czech Diplomatic Service.

Dr. N. H. Fairley, to the Wellcome chair of tropical medicine tenable at the London School of Hygiene and Tropical Medicine as from October 1. He has been lecturer in clinical tropical medicine at the School and lecturer in tropical medicine at Westminster Hospital. During 1916-19 he was pathologist and later senior physician in the 14th Australian General Hospital ; since 1942 he has been Director of Medicine to the A.M.F.

Dr. George Macdonald, to the University chair of tropical hygiene tenable at the London School of Hygiene and Tropical Medicine as from October 1. In 1939 he was appointed assistant director of the Ross Institute at the London School of Hygiene and Tropical Medicine, but he joined the R.A.M.C. and became officer commanding various malaria field laboratories in the Near and Middle East. During 1943-44 he was consultant malariologist to the Middle East and Central Mediterranean Forces, and in 1945 he was appointed director of the Ross Institute of the School.

Prof. J. T. Randall, to the Wheatstone chair of physics tenable at King's College as from October 1 ; since 1944, he has been professor of natural philosophy in the University of St. Andrews (see Nature, 156, $685 ; 1945)$.

Dr. R. M. Barrer, to the University readership in chemistry tenable at Bedford College as from October 1. During 1935-39 he was supervisor in chemistry and research fellow of Clare College, Cambridge, and since 1939 he has been head of the Ohemistry Department at Bradford Technical College.

Mr. Edward A. Shils, to the University readership in sociology tenable at the London School of Economics from October 1. During 1942-44 he was in London on work in connexion with the Federal Communications Commission and SHAEF ; he is at present associate professor of sociology in the University of Chicago.

Dr. F. C. O. Valentine, to the University readership in chemotherapy tenable at the London Hospital Medical College as from October 1. Since 1939 he has been pathologist, Emergency Medical Service.

\section{British Association: New Officers}

Ir is anngriced by the British Association that the following hanges in office bearers have been approved by the General Committee: President, Sir Henry Dale, to succeed Sir Richard Gregory on January 1, 1947 (see Nature, July 27, p. 124); General Officers (with effect from July 20, 1946) : Treasurer, Mr. M. G. Bennett, to succeed Sir Harold Hartley; General Secretaries, Dr. E. Hindle and Sir John LennardJones, to succeed Prof. F. T. Brooks, Prof. D. Brunt and Prof. Allan Ferguson; Secretary, Mr. D. N. Lowe, to succeed Dr. O. J. R. Howarth.

Erray $1 M$. The author of a paper, referred to in Nature of March 9, p. 311, on the residual toxicity of D.D.T. to bedbugs, is incorrectly given as Miss Sarah Banks; the author is Dr. Sarah Barnes. 